\title{
AN EXPERIMENTAL APPROACH TO THE STUDY OF AG-NOR PROTEINS
}

\author{
Rosa M. RODRIGO, José TORREBLANCA, Gregorio GARCÍA-HERDUGO \\ and Francisco J. MORENO
}

Department of Cell Biology, Faculty of Biology, University of Seville, Spain

Received for publication May 9, 1994

\begin{abstract}
Purified polyclonal antibodies have been obtained against $100 \mathrm{KD}$ and $36 \mathrm{KD}$ Ag-NOR proteins. These two antibodies have been used to study the immunolocalization of both proteins on different cell types subjected to various conditions of cell activity and to observe a nucleolar labelling with anti-36 kDa Ag-NOR protein antibody evenly distributed over the dense fibrillar component and granular component, and with anti-100 kDa mainly localized to the dense fibrillar component. After actinomycin $D$ treatment, immunolabelling with both antibodies was found restricted to the granular zone of segregated nucleoli. Moreover, to further study the functional role of these proteins, we have used an electroporation system to introduce both antibodies into the nuclei of living cells, and have clearly detected a different nucleolar behaviour. The combination of these techniques has been shown to be an important tool to deepen the knowledge of the nucleolus and has allowed us to propose that the difference in nucleolar localization of the major $36 \mathrm{kDa}$ and $100 \mathrm{kDa} \mathrm{Ag}-\mathrm{NOR}$ proteins is the consequence of a different role of both proteins in the synthesis and processing of rRNA.
\end{abstract}

The nucleolus represents a distinct biochemical and morphological structure of eukaryotic cell nuclei where the synthesis and processing of rRNAs and the assembly of precursors for the large and small ribosomal subunits occur $(14,21,25,45)$. To better understand this complex process of ribosome biogenesis, it would be of great importance to elucidate the function of the different nucleolar proteins that participate in it, without being part of mature cytoplasmic ribosomes.

Nucleoli gossess a high affinity for silver staining, this argirophilicity being due to the presence of some non-histone acidic proteins, the Ag-NOR proteins. Between the more likely candidates for argyrophilic proteins are found the C23 and B23 proteins and also the larger subunits of RNA polymerase I, but the exact nature of Ag-NOR proteins is still controversial. Protein B23, also called nucleophosmin, NO38 or numatrin, is a $36-38 \mathrm{kDa}$ nucleolar phosphoprotein which is more abundant in proliferating than in resting cells, and may be involved in assembly and/or transport of ribosomes $(20,46,54)$. Protein C23, also

Correspondence to: Francisco J. Moreno, Departamento de Biología Celular, Facultad de Biología, Universidad de Sevilla, Avenida Reina Mercedes ${ }^{\circ}$ 6, 41012-Sevilla, Spain. called nucleolin, is another abundant nucleolar phosphoprotein, with a molecular mass of around $100 \mathrm{kDa}$, which seems to be involved in the early stages of ribosome biogenesis and to be associated with rDNA-containing structures $(19,44,48)$. The interest in Ag-NOR proteins started with the finding that their amount is directly related to the degree of transcriptional activity, its detection being used as a marker of nucleolar activity and cell proliferation (10, $12,15,23,30,34,35,38,40$ ).

To elucidate the role of these proteins on nucleolar activity it would be important to introduce antibodies against them into cell nuclei and to study the induced modifications. Some experimental approaches have already been carried out by means of microinjection of antibodies against major nucleolar proteins into the cytoplasm of cultured cells (5) and of anti-C23 into cell nuclei (16). It is known that immunoglobulins cannot passively diffuse through nuclear pores $(17,50,51)$, therefore we planned an approach by means of an electroporation system. Electroporation involves the application of high-voltage electric field pulses of short duration to induce the formation of transient pores in the membranes of cells. Under appropriate conditions, the diffusion and exchange of intracellular and extracellular components 
can take place during the lifespan of the pore, and macromolecules such as antibodies or DNA present in the suspending medium may enter into the treated cell $(53,55)$. Electroporation thus can be regarded as a massive microinjection technique that can be used to inject a single cell or millions of cells with specific components in the culture medium (9).

As already explained, NOR-silver staining is being used as a marker of nucleolar activity and cell proliferation. Several studies have been carried out on the immunolocalization and functional role of proteins B23 and C23 in the nucleolus by using monoclonal or polyclonal antibodies against such proteins and the results have been put in relation to Ag-NOR proteins. However, in the present study we have assayed polyclonal antibodies obtained directly from the major $100 \mathrm{kDa}$ and $36 \mathrm{kDa} \mathrm{Ag}-\mathrm{NOR}$ proteins, detected after NOR-silver staining, in order to investigate their immunolocalization and behaviour in different conditions of cell activity. Moreover, to increase the knowledge about the functional role of these proteins we have observed the nucleolar behaviour by means of the introduction of both purified antibodies into living cells using electroporation techniques. Our results after morphological, cytochemical, immunocytochemical and morphometric studies allow us to suggest a different nucleolar localization and function of both $\mathrm{Ag}-\mathrm{NOR}$ proteins on ribosomal biosynthesis.

\section{MATERIALS AND METHODS}

\section{Cell culture}

Sl-29 cells (American Type Culture Collection, ATCC, Maryland, USA) were cultured in Minimum Essential Medium (Sigma, St. Louis, MO, USA) supplemented with $5 \%$ denatured foetal bovine serum, $5 \%$ tryptose phosphate broth, $25 \mathrm{ng} / \mathrm{ml}$ fibroblast growth factor (Sigma), $100 \mathrm{U} / \mathrm{ml}$ penicillin-streptomycin, $1 \%$ fungizone and 1\% antiPPLO (Gibco BRL).

TG cells were grown and maintained in cell culture flasks containing Dulbecco's medium (Gibco BRL) supplemented with 10\% FBS, 2 mM glutamine, $1 \mathrm{mM}$ sodium pyruvate, $100 \mathrm{U} / \mathrm{ml}$ penicillin-streptomycin, $1 \%$ fungizone, and 1\% antiPPLO.

For actinomycin D (AMD) experiments, 75\% confluent SL-29 cells were incubated with $0.05 \mu \mathrm{g} / \mathrm{ml}$ to $1 \mu \mathrm{g} / \mathrm{ml}$ AMD (Fluka, Buchs, Switzerland) for $6 \mathrm{hr}$. After this treatment, cells were processed for immunofluorescence and immunoelectron microscopy.

\section{Antibodies}

Each antiserum was produced in two different rab- bits by subcutaneous injections of crushed gel slices containing the $100 \mathrm{kDa}$ or $36 \mathrm{kDa} \mathrm{Ag}$-NOR proteins, identified by means of the NOR-silver staining on gels (35), and obtained by preparative gel electrophoresis from whole protein extracts of animal cells as previously described (24). Antisera were concentrated by ammonium sulfate precipitation, dialyzed against PBS, affinity-purified according to Olmsted (1981) (36), and desalted with Econo-Pac 10 DG Columns (Bio-Rad, Richmond, CA). Finally, polyclonal antibodies against $36 \mathrm{kDa}$ and $100 \mathrm{kDa} \mathrm{Ag}$-NOR proteins were concentrated with Centrifugal Ultrafree-20 Filter Units (Millipore, Bedford, MA).

\section{Immunofluorescence}

Cells grown on glass coverslips to $75 \%$ confluence were treated for immunofluorescence as previously described (41). As the first antibody step, cells were incubated with a $1: 25$ to $1: 100$ dilution of our antibodies against $36 \mathrm{kDa}$ or $100 \mathrm{kDa} \mathrm{Ag}$-NOR proteins in $\mathrm{PBS}$ for $45 \mathrm{~min}$ a $37^{\circ} \mathrm{C}$ in a humidified chamber. Second antibody incubation was performed with a $20 \mu \mathrm{g} / \mathrm{ml}$ dilution of affinity-purified sheep anti-rabbit IgG-fluorescein, F (ab') $)_{2}$ fragment (Boehringer Mannheim Biochemicals, Indianapolis, IN) in PBS with $0.5 \%$ BSA for $45 \mathrm{~min}$ at $37^{\circ} \mathrm{C}$.

Slide specimens were photographed on an Olympus Vanox AHBT3 fluorescence microscope. Micrographs were prepared with a Kodak TRI-X-PAN film processed to $400 \mathrm{ASA}$.

\section{Electron microscopy}

Cells were processed for morphological and immunocytochemical electron microscopic studies after reaching $75 \%$ confluence. For the morphological study, they were fixed in $1.6 \%$ glutaraldehyde in $0.1 \mathrm{M}$ cacodylate buffer, $\mathrm{pH} 7.2$, for $60 \mathrm{~min}$ at $4^{\circ} \mathrm{C}$ and post-fixed in $1 \%$ osmium tetroxide for $60 \mathrm{~min}$ at $4^{\circ} \mathrm{C}$. Samples were dehydrated in acetone at progressively higher concentrations and embedded in resin (49).

For the cytochemical study, cells were fixed in $1.6 \%$ glutaraldehyde in $0.1 \mathrm{M}$ cacodylate buffer,

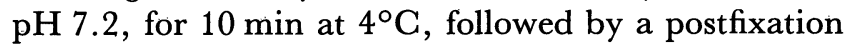
in Carnoy's solution (1:3 (v/v) acetic acid: ethanol) for $10 \mathrm{~min}$ at $4^{\circ} \mathrm{C}$.

For electron microscopic immunolocalization, cells were fixed in a mixture of $4 \%$ paraformaldehyde and $0.1 \%$ glutaraldehyde in $0.1 \mathrm{M}$ cacodylate buffer, $\mathrm{pH} 7.3$, for $60 \mathrm{~min}$ at $4^{\circ} \mathrm{C}$.

Fixations were performed on the culture flasks and subsequently, cells were scraped and pelleted by centrifugation. Samples were incubated in $0.5 \mathrm{M}$ 
$\mathrm{NH}_{4} \mathrm{Cl}$ for $4 \mathrm{hr}$ at room temperature to block free aldehyde groups.

\section{Lowicryl K4M-embedded sections}

Low-temperature embedding with the hydrophilic resin Lowicryl K4M (Chemische Werke Lowi., Waldkraiburg, FRG) was performed according to the method described by Roth (42), with slight modifications (33).

\section{Cryoultramicrotomy}

TG cells were fixed in 4\% paraformaldehyde and $0.1 \%$ glutaraldehyde in $0.1 \mathrm{M}$ cacodylate buffer $\mathrm{pH}$ 7.2, washed in cacodylate buffer and PBS, scraped from the culture plates and pelleted after centrifugation. Pellets were embedded in $10 \%$ polyvinylpyrrolidone (PVP) in 2.3 M sucrose and processed for cryoultramicrotomy.

Ultrathin sections were cut on a Reichert-Jung Ultracut E ultramicrotome, mounted on 300-mesh copper or nickel grids and photographed in a Philips CM10 transmission electron microscope (Servicio de Microscopía Electrónica, University of Seville).

One-step silver staining

This technique was applied, following Howell and Black (28) and Ploton et al. (39), with the modifications of Moreno et al. (33).

\section{Immunocytochemical labelling}

Grids were treated as previously described (41). The first incubation step was carried out in polyclonal antibodies against $36 \mathrm{kDa}$ or $100 \mathrm{kDa} \mathrm{Ag}-\mathrm{NOR}$ proteins diluted $1: 10$ to $1: 100 \mathrm{in}$ PBS for $1 \mathrm{hr}$ to $24 \mathrm{hr}$ at room temperature. Labelling was performed in protein A-gold complex prepared following Bendayan et al. (1) and diluted according to Roth et al. (43).

\section{Electroporation}

Exponentially growing TG cells were harvested and resuspended in HeBS $(20 \mathrm{mM}$ Hepes, $137 \mathrm{mM}$ $\mathrm{NaCl}, 5 \mathrm{mM} \mathrm{KCl}, 0.7 \mathrm{mM} \mathrm{Na} \mathrm{HPO}_{4}, 6 \mathrm{mM}$ dextrose) at a final concentration of $6 \times 10^{6}$ cells per milliliter. Antibodies against $36 \mathrm{kDa}$ or $100 \mathrm{kDa} \mathrm{Ag}-$ NOR proteins were added to the medium at a final dilution of $1: 20$ and kept at room temperature for $10 \mathrm{~min}$. Cells were transferred to pre-chilled cuvette chambers (2 mm gap), and electroporated in a BTX Electro Cell Manipulator 600 Electroporation System (Biotechnologies \& Experimental Research Inc., San Diego, CA) at a capacitance level of $1600 \mu \mathrm{F}$. Each pulse was delivered at an average peak field strength of $1.6 \mathrm{KV} / \mathrm{cm}$ for $10 \mathrm{msec}$ and after $10 \mathrm{~min}$ at room temperature, the cells were removed from the chamber and seeded in culture plates. After $6 \mathrm{hr}$ of culture, living cells were fixed in $1.6 \%$ glutaraldehyde, processed for morphological electron microscopic studies, as already described, and for a subsequent morphometric study. Controls were performed after the electroporation of TG cells in the absence of antibodies but with the application of the same electric pulses.

Conditions for electroporation were chosen in a way that maximum penetration to the nucleus and highest viability of cells could be attained. The study of cell viability and of penetration into the cytoplasm was carried out using the unpermeant dye trypan blue. The percentage of permeabilized cells was the number of blue-stained cells measured as a percentage of the total number of cells. The introduction of antibodies into the nucleolus was followed using affinitypurified sheep anti-rabbit IgG-fluorescein (Boehringer Mannheim Biochemicals) as the second antibody after the fixation of electroporated cells.

\section{Morphometric and stereological analysis}

This study was carried out on 40 images per group of nucleoli chosen at random, taken from ultrathin sections of normal TG cells, control TG electroporated cells and TG cells electroporated with polyclonal antibodies against $36 \mathrm{kDa}$ and $100 \mathrm{kDa} \mathrm{Ag}-$ NOR proteins. Images were digitalized, processed and analyzed in the IMAGO automatic image analysis system (Servicio de Microscopía Electrónica, University of Seville). The parameter measured was the nucleolar area on each group of cells.

Data were analyzed statistically by the Student's t-test. A statistical difference was considered when $\mathrm{p}<0.01$.

\section{Mono-dimensional gel electrophoresis (SDS-PAGE)}

SL-29 and TG cells were trypsinized from culture flasks after attaining 75\% confluence, washed in PBS and pelleted after a mild centrifugation. Extraction of proteins and electrophoresis on 12\% SDS-polyacrylamide gels using the Mini-Protean II electrophoresis cell (Bio-Rad., Richmond, CA) were performed as described by Laemmli (29). A set of molecular mass standards were obtained from Bio-Rad and of pre-stained molecular mass standards from Fluka.

Total proteins in gels were revealed with Coomassie blue staining.

\section{Electrophoretic transfer and immunoblotting}

Proteins were transferred electrophoretically from polyacrylamide gels to nitrocellulose paper (52). The first incubation step was performed in antibodies against $36 \mathrm{kDa}$ or $100 \mathrm{kDa} \mathrm{Ag}-\mathrm{NOR}$ proteins diluted 
$1: 100$ to $1: 1000$. Horseradish peroxidase labelled goat anti-rabbit IgG (Bio-Rad) diluted $1: 3000$ was used for the second antibody incubation. The reaction was visualized with chloronaphthol substrate.

One-step NOR-silver staining on nitrocellulose membranes was performed as previously described (41).

Photographs of gels and transfers were taken with an AGFA Copex Rapid A.H.U. film processed to 9 ASA.

\section{RESULTS}

Purified polyclonal antibodies were obtained, as previously described, against Ag-NOR proteins isolated from gels after application of the NOR-silver staining and selection of those migrated at $100 \mathrm{kDa}$ and $36 \mathrm{kDa}$. To characterize the nucleolar antigens recognized by these antibodies we carried out monodimensional gel electrophoresis of whole cell extracts obtained from SL-29 and TG cells, followed by electrophoretic transfer. We found two polypeptides which respectively migrated at 36 and $100 \mathrm{kDa}$ immunoblotted with our polyclonal antibodies. After NOR-silver staining on nitrocellulose membranes, two positive main bands were detected in the same migration position as with the antibodies, together with a protein at $28 \mathrm{kDa}$ and other bands not so clearly visible. Corresponding Coomassie-stained gels of cell extracts showing the full complement of extracted proteins and negative control assay in which antibodies were excluded confirmed the blotting immunospecificity (Fig. 1).

Under immunofluorescence microscopy and after immunolabelling with a $1: 25$ to $1: 100$ dilution of our polyclonal antibodies against $36 \mathrm{kDa}$ or $100 \mathrm{kDa} \mathrm{Ag}$ NOR proteins on fixed SL-29 cells a bright nucleolar fluorescence could be observed (Figs. 2, 3). On the other hand, SL-29 cells treated with 0.05 to $1 \mu \mathrm{g} / \mathrm{ml}$ AMD showed an intense labelling with both antibodies restricted to nucleolar crescent zones and also a bright nuclear fluorescence suggesting a translocation of both proteins from the nucleolus to the nucleoplasm (Figs. 4, 5).

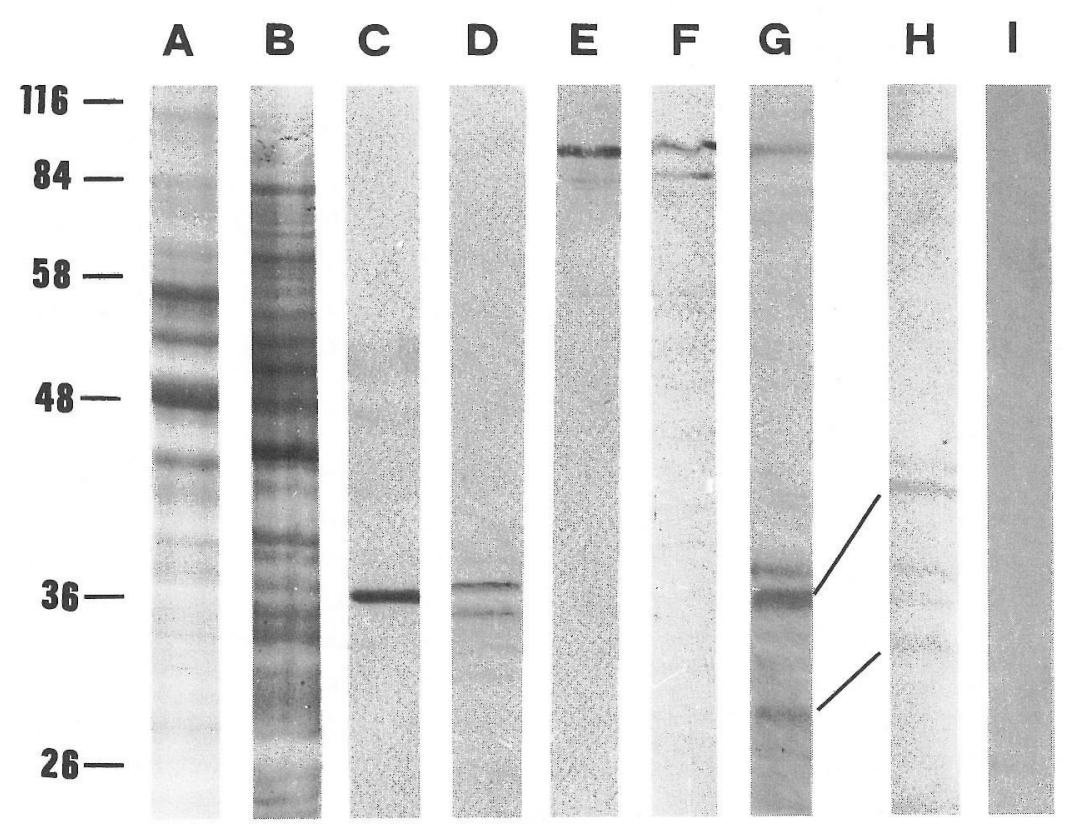

FIG. 1. Coomassie blue staining of 12\% PAGE-separated proteins present in whole cell extracts of (A) SL-29 cells and (B) TG cells, and the respective characterization by immunoblotting of the antigens recognized by our polyclonal antibodies against AgNOR proteins. Two polypeptides at 36 and $100 \mathrm{kDa}$, are revealed upon probing with our anti-36 kDa $(\mathrm{C}, \mathrm{D})$ and anti-100 kDa (E, F) polyclonal antibodies respectively in (C, E) SL-29 cells and (D, F) TG cells. After NOR-silver staining on Western-blotted proteins from whole extracts of $(\mathrm{G})$ SL-29 cells and $(\mathrm{H}) \mathrm{TG}$ cells, two positive main bands are visible in the same migration position as with the antibodies, together with a band at $28 \mathrm{kDa}$. (I) Corresponding negative control assay in which antibodies were excluded. 
At the ultrastructural level, SL-29 cells frequently disclosed reticulate nucleoli characterized by a network of threads, or nucleolonema. Some fibrillar centres (FCs) could be detected total or partially surrounded by dense fibrillar component (DFC). Granular component (GC) and interstices usually appeared between the nucleolonema threads (Fig. 6). When we proceeded to NOR-silver staining on SL-29 cells specific silver precipitate was localized mainly over both the FCs and DFC and also over the nucleolonema threads, but not localized over GC (Fig. 7). Immunolabelling on SL-29 cells after applying both antibodies against the $36 \mathrm{kDa}$ and $100 \mathrm{kDa} \mathrm{Ag}-\mathrm{NOR}$ pro- teins was found over the nucleolonema threads, DFC and GC. The FGs were devoid of gold particles. However, we observed that immunolabelling with anti-100 kDa displayed a higher density of gold grains localized over the DFC, in close association to the FCs, than in the nucleolonema threads, while anti$36 \mathrm{kDa}$ antibody was more equally distributed over the DFC and GC (Figs. 8, 9).

Following a $6 \mathrm{hr}$ exposure of SL-29 cells to $1 \mu \mathrm{g} /$ ml AMD, electron microscopy revealed a characteristic segregation of nucleolar main components, with the fibrillar component separated from the granular component and the amorphous zone (Fig.

Figs. 2-5. Immunofluorescence microscopy on SL-29 cells (Figs. 2, 3) and SL-29 cells treated with $1 \mu \mathrm{g} / \mathrm{ml}$ AMD (Figs. 4, 5), fixed in 3\% formaldehyde after incubation with anti-36 kDa protein (Figs 2, 4) and anti-100 kDa protein (Figs. 3, 5) antibodies.

Figs. 2, 3. a. Fluorescence in reticulate nucleoli is detected after incubation with both polyclonal antibodies. b. Corresponding Hoechst staining. Fig. $2 \times 1,000$ Fig. $3 \times 1,150 \quad$ Bars $=10 \mu \mathrm{m}$

Figs. 4, 5. a. Upon treatment with AMD, SL-29 cells show an intense labelling with both antibodies restricted to nucleolar crescent zones and a bright nuclear fluorescence. b. Corresponding Hoechst staining. $\quad \times 1,200 \quad$ Bars $=10 \mu \mathrm{m}$

Fig. 6. Reticulate nucleoli of SL-29 cells disclosing a network of threads, with some fibrillar centres (arrow) surrounded by dense fibrillar component, granular component and interstices. Cells were fixed in 1.6\% glutaraldehyde, post-fixed in $1 \%$ osmium tetroxide and embedded in Spurr resin. Uranyl acetate and lead citrate counterstaining. $\quad \times 50,000 \quad \mathrm{Bar}=0.2 \mu \mathrm{m}$

FIG. 7. NOR-silver staining on SL-29 cells mainly over the fibrillar centres (arrows) and dense fibrillar component. Cells were fixed in glutaraldehyde-Carnoy and embedded in Lowicryl K4M. $\times 45,500 \quad \mathrm{Bar}=0.2 \mu \mathrm{m}$

Figs. 8, 9. Immunolabelling with our polyclonal antibodies against Ag-NOR proteins on SL-29 cells fixed in $4 \%$ paraformaldehyde- $0.1 \%$ glutaraldehyde and embedded in Lowicryl K4M.

Fig. 8. Immunolabelling with anti-36 kDa antibody is found over the nucleolonema threads, dense fibrillar component and granular component. Fibrillar centres are free of labelling. $\times 36,800 \quad$ Bar $=0.2 \mu \mathrm{m}$

Fig. 9. After using anti-100 kDa antibodies gold particles are localized to the nucleolonema threads, dense fibrillar component and granular component. A higher density of gold grains is localized to the dense fibrillar component. $\quad \times 40,300 \quad \mathrm{Bar}=0.2 \mu \mathrm{m}$

FIGs. 10-12. SL-29 cells treated with $1 \mu \mathrm{g} / \mathrm{ml}$ AMD for $6 \mathrm{hr}$.

Fig.10. Characteristic nucleolar segregation with the fibrillar component (F) separated from the granular component (G). Cells were fixed in $1.6 \%$ glutaraldehyde, post-fixed in $1 \%$ osmium tetroxide and embedded in Spurr resin. Uranyl acetate and lead citrate counterstaining. $\times 72,800 \quad \mathrm{Bar}=0.1 \mu \mathrm{m}$

Figs.11, 12. Gold labelling is mainly found over the granular zone (G) of nucleoli after using our anti-36 kDa (Fig. 11) and anti$100 \mathrm{kDa}$ (Fig. 12) polyclonal antibodies. Cells were fixed in $4 \%$ paraformaldehyde- $0.1 \%$ glutaraldehyde and embedded in Lowicryl K4M. Fig. $11 \times 67,600 \quad$ Bar $=0.1 \mu \mathrm{m} \quad$ Fig. $12 \times 53,100 \quad$ Bar $=0.2 \mu \mathrm{m}$

Fig.13. Compact nucleolus of a TG cell showing fibrillar centres (arrows) surrounded by dense fibrillar component, and immersed in the granular component. Cells were fixed in $1.6 \%$ glutaraldehyde, post-fixed in $1 \%$ osmium tetroxide and embedded in Spurr resin. Uranyl acetate and lead citrate counterstaining. $\quad \times 40,600 \quad \mathrm{Bar}=0.2 \mu \mathrm{m}$

Fig.14. Immunolabelling with anti-36 kDa antibody on nucleoli of TG cells fixed in $4 \%$ paraformaldehyde- $0.1 \%$ glutaraldehyde and embedded in Lowicryl K4M. Gold particles are localized to the dense fibrillar component and granular component. Fibrillar centres are devoid of labelling (arrows). $\quad \times 32,100 \quad$ Bar $=0.2 \mu \mathrm{m}$

Figs.15, 16. Immunolocalization with our antibodies on cryosections of TG cells fixed in $4 \%$ paraformaldehyde- $0.1 \%$ glutaraldehyde and embedded in 10\% PVP in $2.3 \mathrm{M}$ sucrose. Labelling with anti-36 kDa antibody is observed over the dense fibrillar component and granular component of nucleoli (Fig. 15). With anti-100 kDa antibody gold particles are mainly over the dense fibrillar component (Fig. 16). Fig. $15 \times 111,800 \quad$ Bar $=0.1 \mu \mathrm{m} \quad$ Fig. $16 \times 63,000 \quad$ Bar $=0.2 \mu \mathrm{m}$

Figs.17-19. TG cells after electroporation in control conditions and with our antibodies. Cells were fixed in $1.6 \%$ glutaraldehyde, post-fixed in 1\% osmium tetroxide and embedded in Spurr resin. Uranyl acetate and lead citrate counterstaining.

Fig.17. TG electroporated control cell showing a compact nucleolus with several small fibrillar centres (arrows) surrounded by dense fibrillar component. $\times 31,900 \quad$ Bar $=0.2 \mu \mathrm{m}$

Fig.18. Nucleolus of a TG cell electroporated with antibody against $36 \mathrm{kDa}$ Ag-NOR protein disclosing small size fibrillar centres (arrows) and a granular component made of numerous small granules and interstices (arrowhead). $\times 25,100 \quad \mathrm{Bar}=0.5 \mu \mathrm{m}$

FIG.19. Nucleolus of a TG cell electroporated with antibody against $100 \mathrm{kDa}$ AG-NOR protein revealing a segregation of the fibrillar component (arrows) and interstices (arrowhead). $\quad \times 34,000 \quad \mathrm{Bar}=0.2 \mu \mathrm{m}$ 

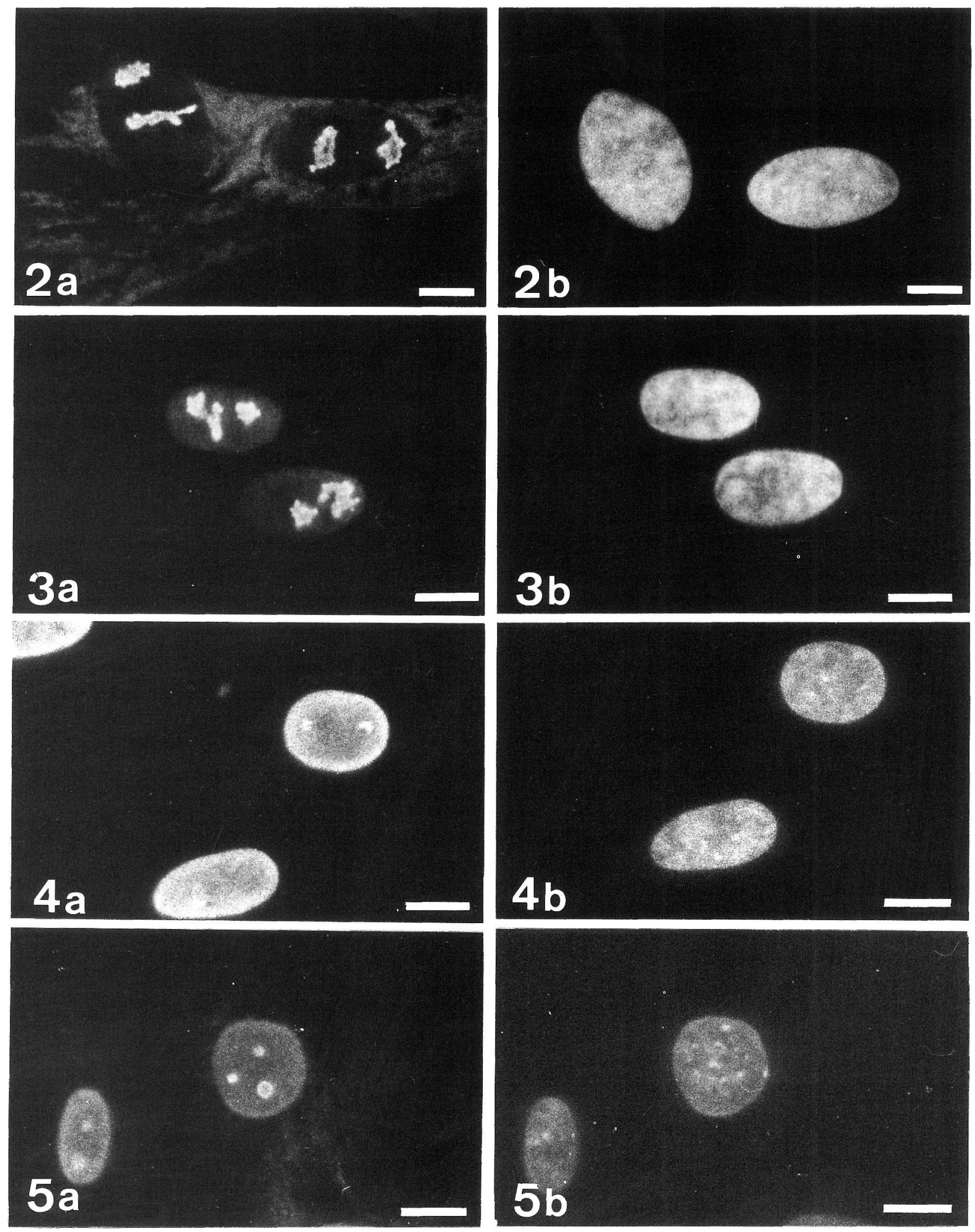

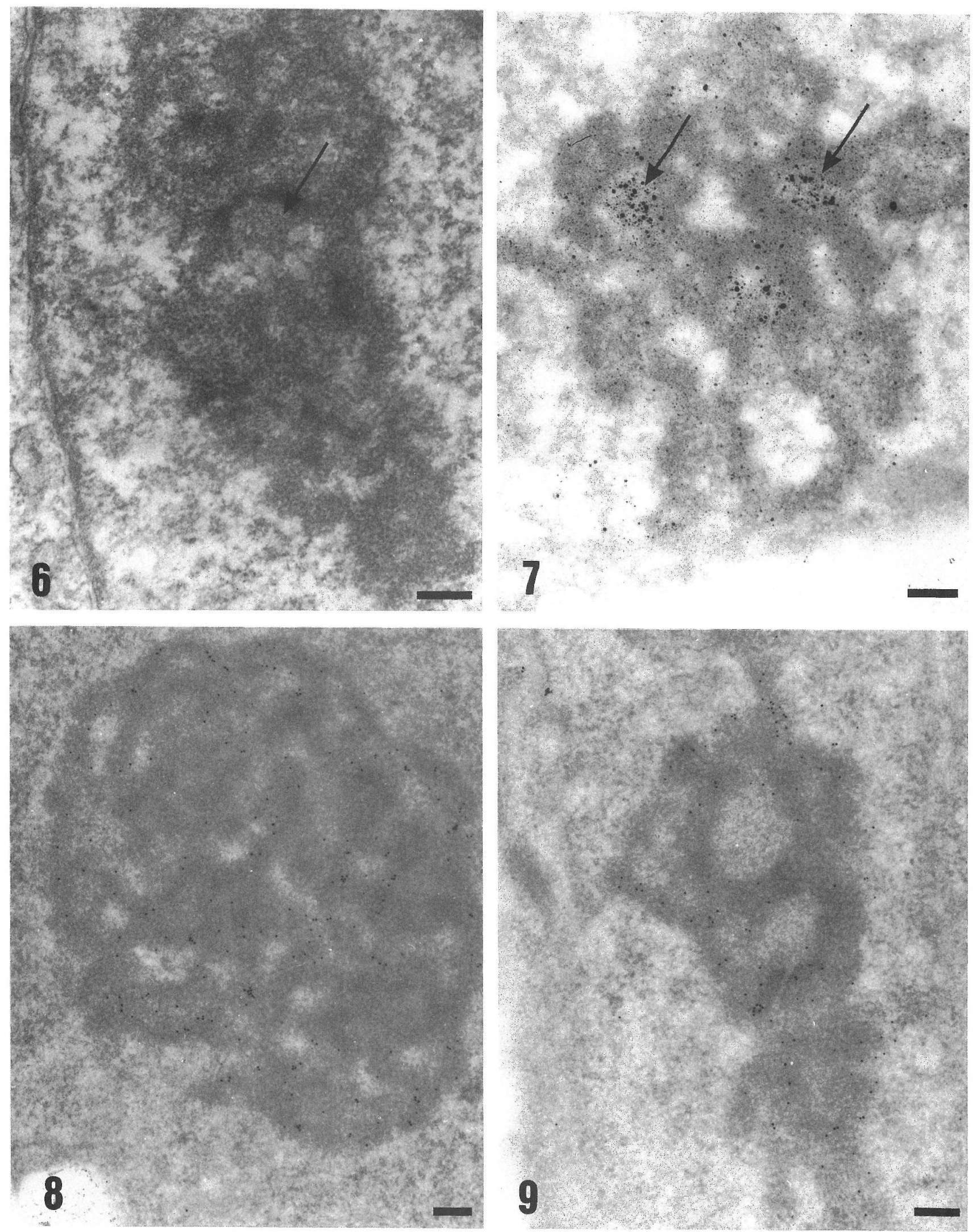


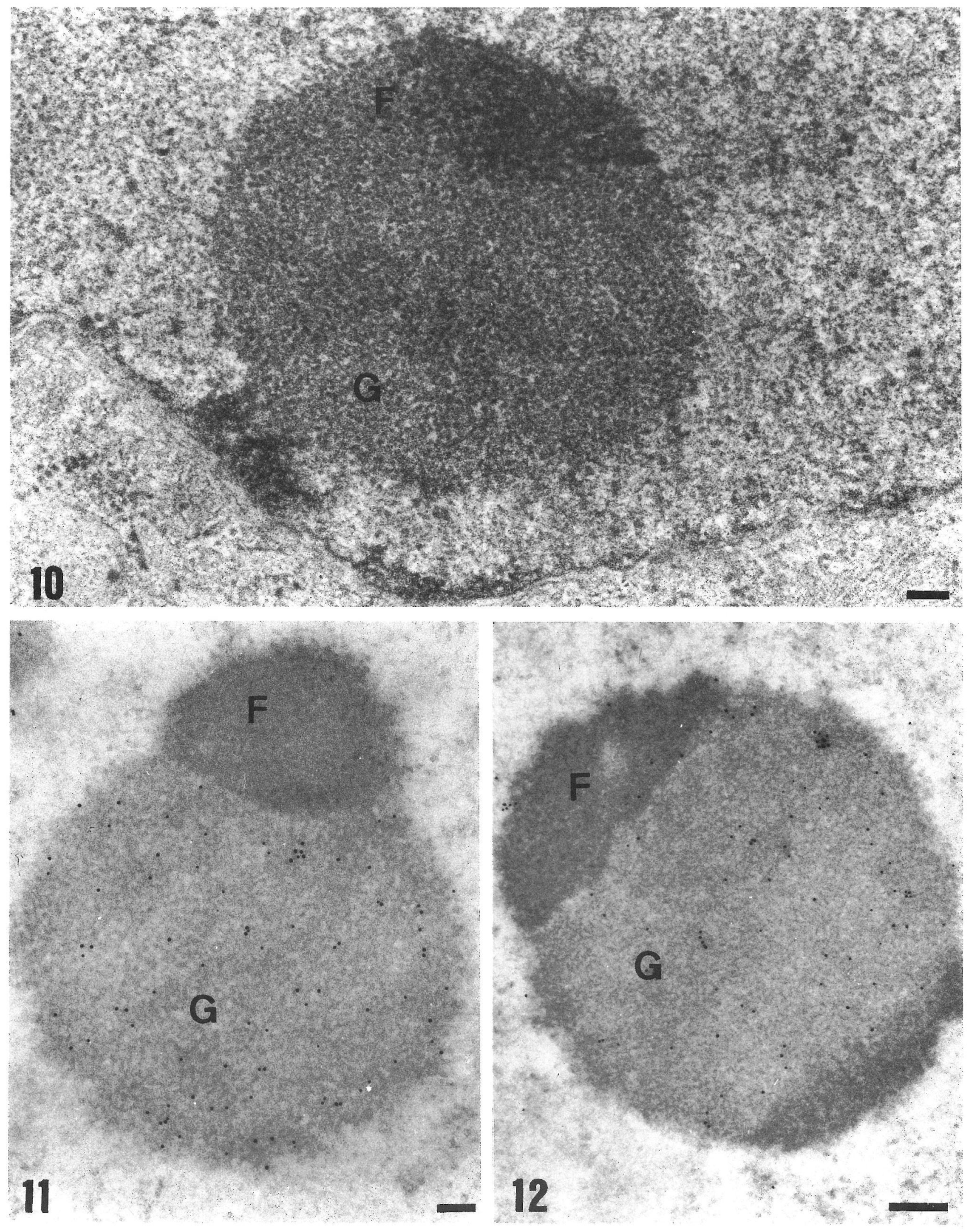




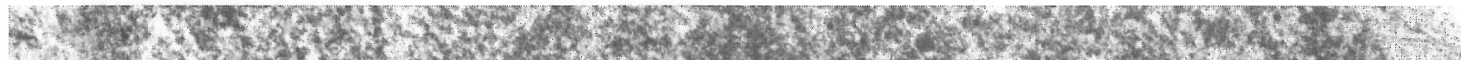
(4)

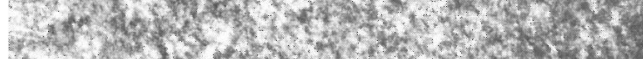

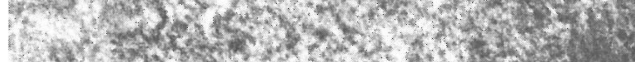

oxcos. W.

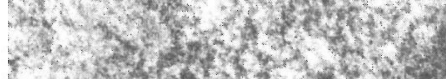
F.

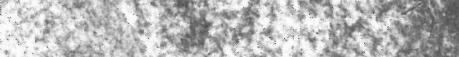

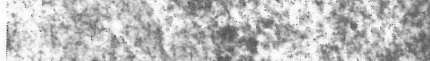

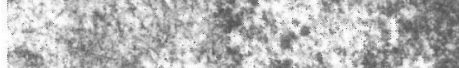

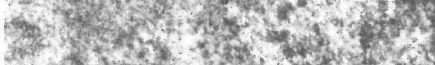

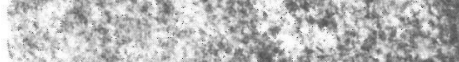
(1)

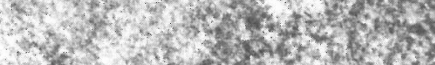
tets

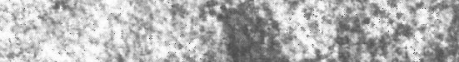

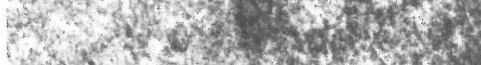
$x^{2}+x^{2}$ $7^{6}$

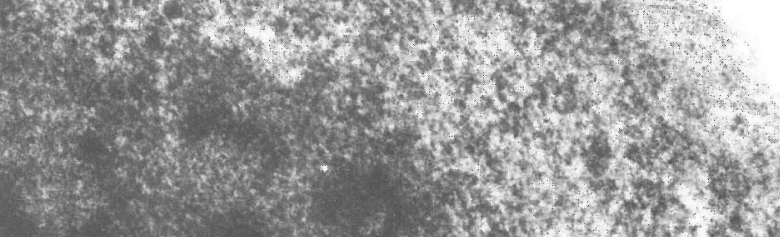

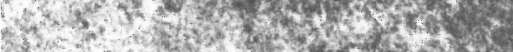

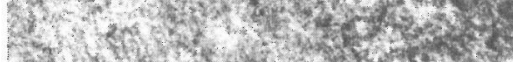

Ain.

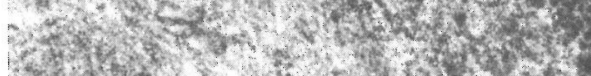

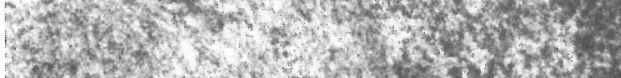

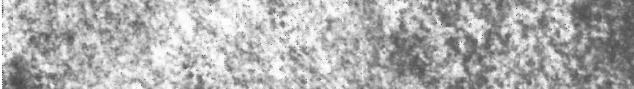

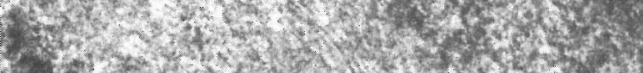

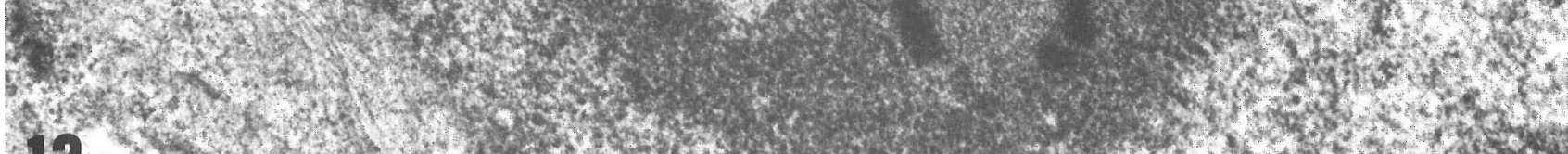
$x^{2}+2$

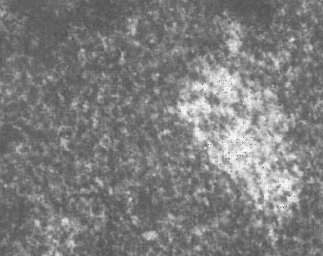
witis

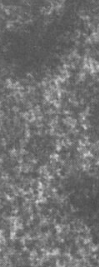

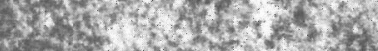

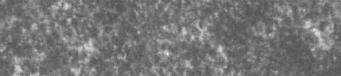

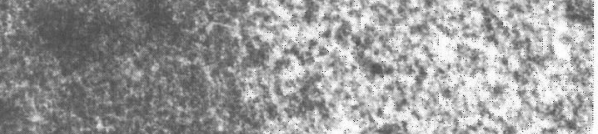

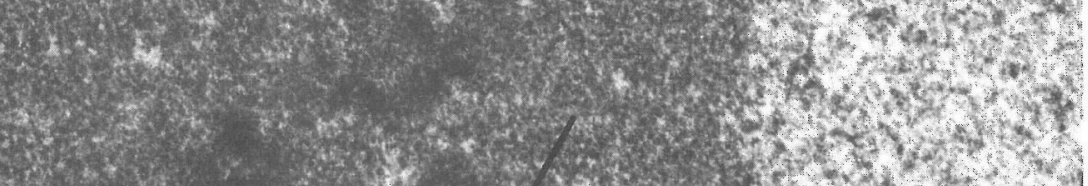

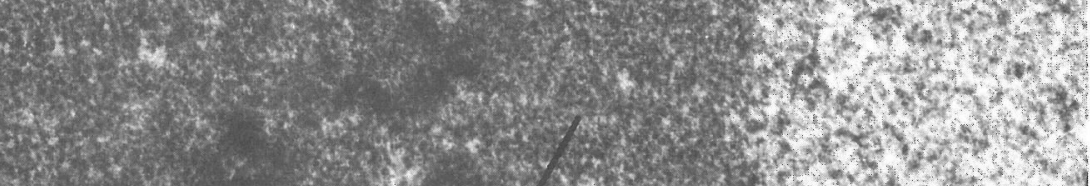

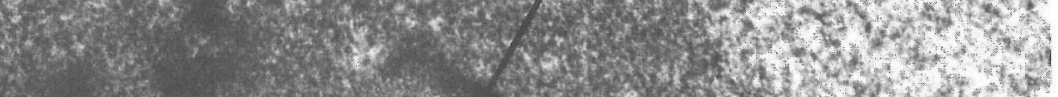

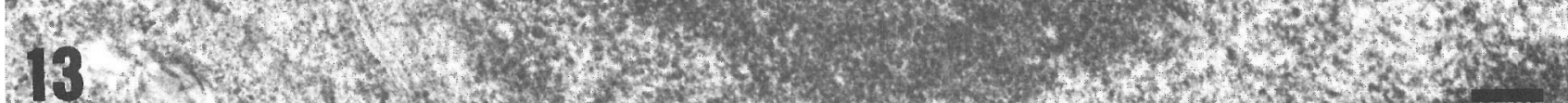
13.
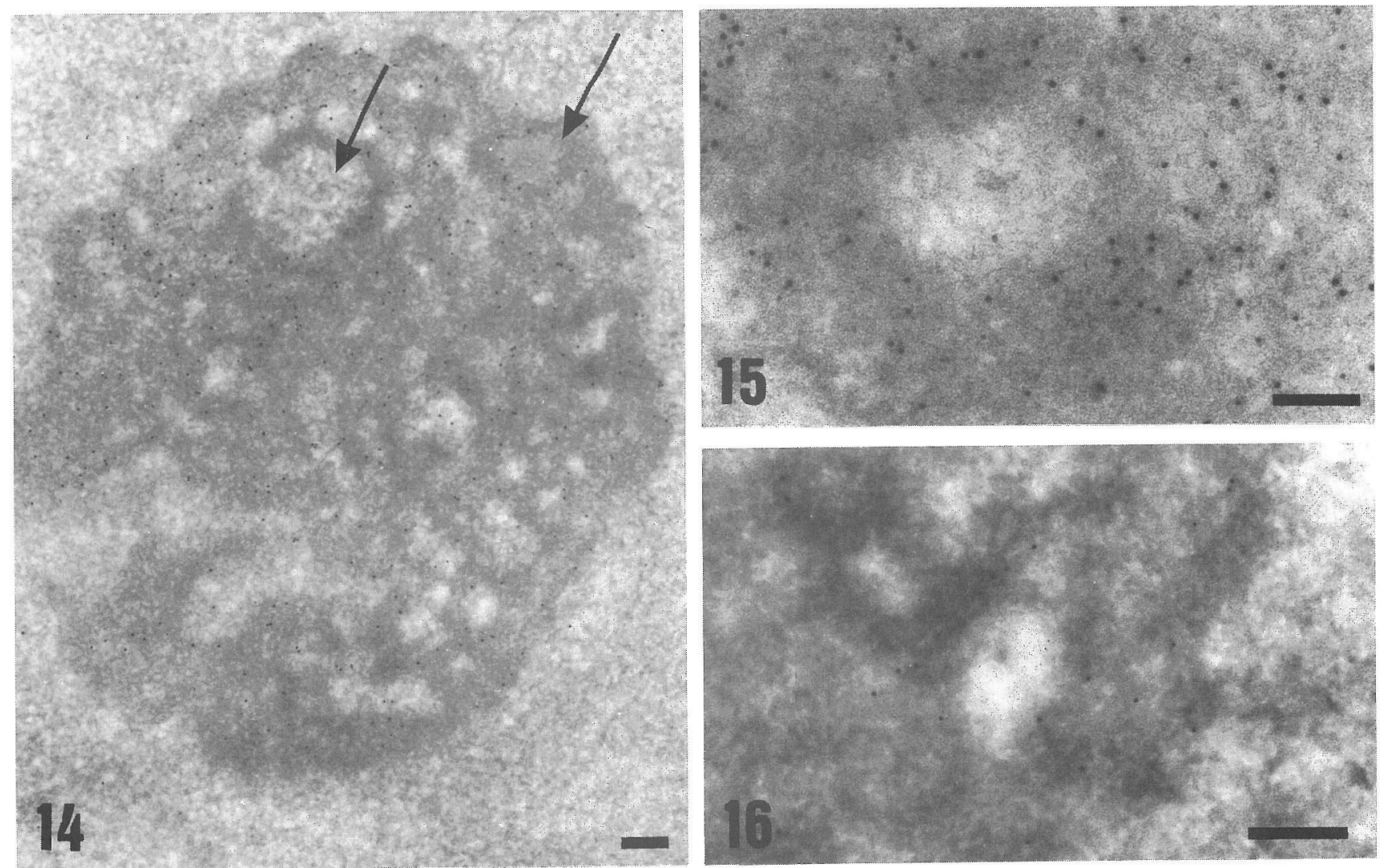

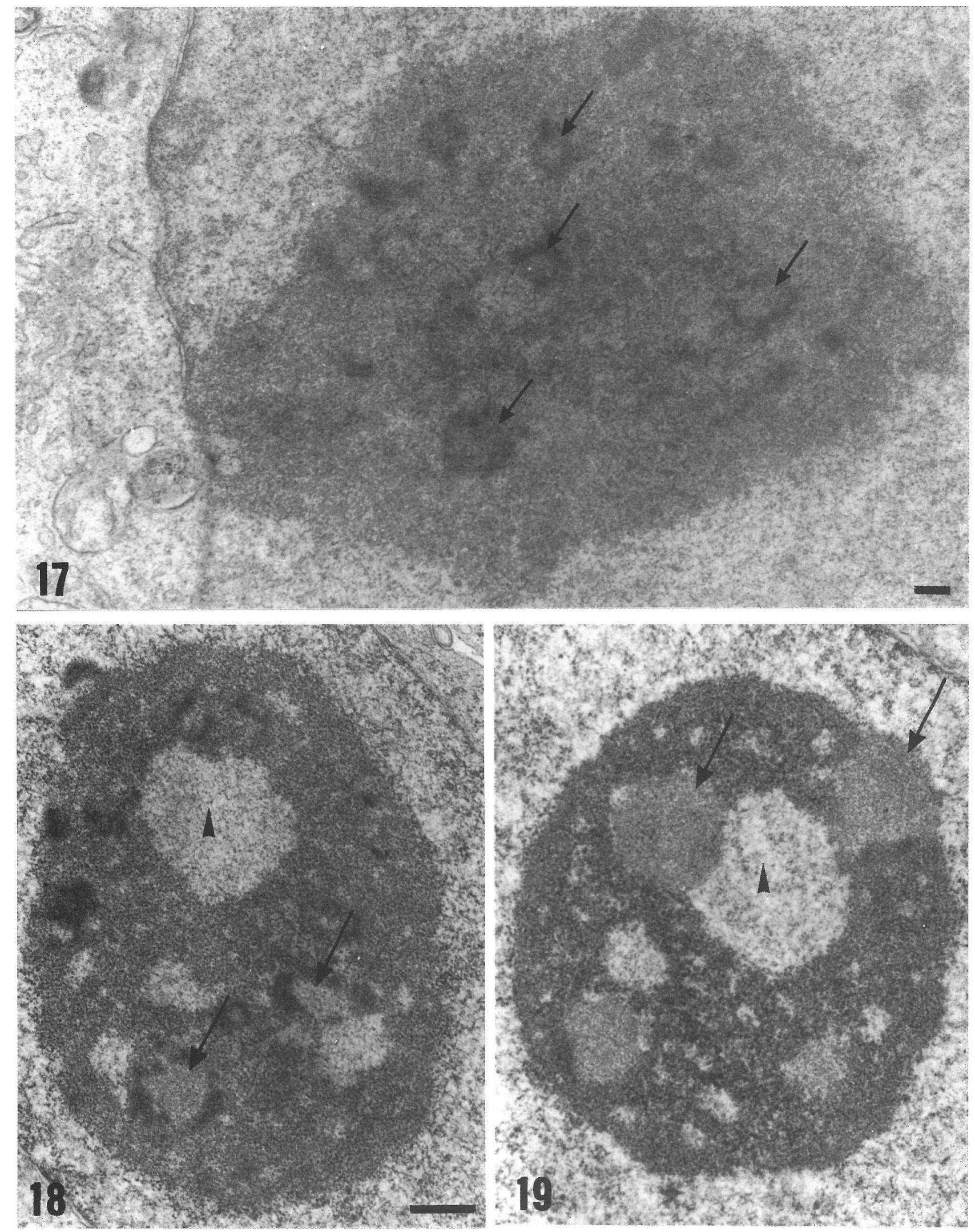
10). Immunolabelling with our polyclonal antibodies against Ag-NOR proteins on SL-29 cells previously exposed to AMD was mainly found over the granular zone of the segregated nucleoli after using both antibodies (Figs. 11, 12).

On the other hand, TG cells disclosed nucleoli with a compact morphology, formed by FCs that were found at least partly surrounded by DFC, and the GC (Fig. 13). After-embedding immunoelectron microscopic localization with anti-36 $\mathrm{kDa}$ antibody in TG cells was detected over the nucleolar DFC and GC (Fig. 14). When immunolabelling with this antibody was performed on cryosections of TG cells a similar distribution of gold particles was observed, localized over the DFC and GC and leaving the FCs free of labelling (Fig. 15), whereas with anti-100 kDa antibody the amount of gold particles was higher over the DFC than in the GC, but the FGs remained without labelling again (Fig. 16).

In order to contribute to elucidate the role of these proteins on nucleoli we proceeded to introduce both antibodies into the nuclei of TG cells. To carry out a real evaluation of the modifications induced in TG cells after electroporation with our polyclonal antibodies we first studied the alterations occurring after the electroporation technique without the introduction of antibodies. At the ultrastructural level we found that TG electroporated control cells showed voluminous compact nucleoli, with several small FGs surrounded by DFC, embedded in the GC (Fig. 17). When the anti-36 kDa antibody was added to the electroporation medium we detected nucleoli with small size FCs, surrounded by DFC, and where the GC disclosed a structure made of numerous small granules perfectly individualized and interstices (Fig. 18). However, when anti-100 kDa antibody was added to the electroporation medium we could easily detect a segregation of the nucleolar fibrillar component of TG cells, where the DFC and FCs could not be distinguished (Fig. 19).
Finally, we carried out the quantitative analysis of cell size after electroporation without the addition of antibodies and we were able to observe an increase in nucleolar size when compared to nucleoli of normal TG cells. After the addition of anti- $36 \mathrm{kDa}$, nucleolar size did not show any statistical difference from nucleoli of TG electroporated control cells. However, when anti- $100 \mathrm{kDa}$ antibody was used, the area of nucleoli was similar to that of normal TG cells but smaller than that found on TG electroporated control cells and TG cells electroporated with anti-36 kDa antibody (Table 1).

\section{DISCUSSION}

Previous studies have revealed that Ag-NOR proteins are associated with active ribosomal genes and it has been demonstrated that they are joined only with the transcribed part of the ribosomal transcriptional units spread on grids $(13,25,44)$. Ag-NOR proteins are detected by a specific silver staining procedure based on the ability of such proteins to reduce silver under acidic conditions $(22,28)$, a mechanism in which has been reported to be involved in the presence of clusters of thiol groups (11). Several studies have shown that NOR-silver staining contrasts the nucleolar fibrillar component differentiating the fibrillar centres from the dense fibrillar component according to their different reaction intensities $(26,33,39)$.

To contribute to elucidating the role of these proteins we first proceeded to obtain purified polyclonal antibodies against the major $100 \mathrm{kDa}$ and $36 \mathrm{kDa} \mathrm{Ag}-$ NOR proteins detected and isolated by means of NOR-silver staining. We tested these antibodies on whole protein extracts of SL-29 and TG cells and observed two polypeptides which migrated at 36 and $100 \mathrm{kDa}$ when immunoblotted with our polyclonal antibodies, respectively, the same migration pattern as the main bands obtained after NOR-silver staining on nitrocellulose membranes.

TABLE 1. Nucleolar area $\left(\mu m^{2}\right)$ measured on normal TG cells, control electroporated TG cells, and TG cells electroporated with polyclonal antibodies against $36 \mathrm{kDa}$ and $100 \mathrm{kDa} \mathrm{Ag}$-NOR proteins

\begin{tabular}{|c|c|c|c|c|}
\hline & Normal & Control & anti-36 kDa & anti-100 kDa \\
\hline $\begin{array}{l}\text { Nucleolar } \\
\text { area }\left(\mu \mathrm{m}^{2}\right)\end{array}$ & $8.21 \pm 0.49$ & $10.47 \pm 0.41^{*}$ & $9.75 \pm 0.52^{*}$ & $8.35 \pm 0.36^{\# \&}$ \\
\hline $\begin{array}{l}\text { mean } \pm \text { s.e.m } \\
*_{\mathrm{p}}<0.01 \mathrm{wl} \\
\# \mathrm{p}<0.01 \mathrm{wl} \\
\& \mathrm{p}<0.01 \mathrm{wl}\end{array}$ & $\begin{array}{l}\text { pared to nor } \\
\text { pared to cor } \\
\text { pared to TG }\end{array}$ & $\begin{array}{l}\text { s cells. } \\
\text { ctroporated TG } \\
\text { lectroporated } \mathrm{W}\end{array}$ & $\mathrm{i}-36 \mathrm{kDa}$ antil & \\
\hline
\end{tabular}


Ultrastructural immunocytochemistry has allowed the study of the distribution of B23 and C23 proteins in various cell types and in different conditions of cell activity $(2-4,19,31,48)$. However, to our knowledge, studies with polyclonal antibodies obtained directly from proteins detected with NOR silverstaining have not been carried out. We have observed the major $100 \mathrm{kDa}$ and $36 \mathrm{kDa} \mathrm{Ag}$-NOR proteins to colocalize in the DFC, nucleolonema threads and GC of nucleoli of SL-29 cells. Immunolocalization with both antibodies on TG cells on cryo-sections however displayed some differences, as the $100 \mathrm{kDa} \mathrm{Ag}-\mathrm{NOR}$ protein was mainly localized to the dense fibrillar component while the $36 \mathrm{kDa}$ protein was found more evenly distributed over the dense fibrillar component and granular component.

Subsequently we proceeded to the cytochemical localization of Ag-NOR proteins after NOR-silver staining, and we detected the specific silver precipitate mainly dispersed over the FCs and DFC, distribution which coincides with that obtained in several studies $(14,33,37,41,56)$. However, our results on the localization of Ag-NOR proteins differ substantially from our immunocytochemical results, as immunolabelling with our polyclonal antibodies has not been detected on the FCs, but on the DFC and GC. Considering that proteins B23 and C23 have been described as the major Ag-NOR proteins, these variations have also been found by other authors, who affirm that staining with silver salts does not parallel the labelling with either the B23 or the nucleolin antibody (4). These data suggest the presence in the FCs of other nucleolar proteins with different molecular masses capable of reducing silver salts that could be responsible for these contradictory results and also allow us to suppose that these proteins might suffer a change in their structure through the mechanisms of synthesis and processing of rRNA in which they are involved.

In order to contribute to the better understanding of the functional role of these Ag-NOR proteins we followed with experiments of inhibition of rRNA synthesis after the addition of drugs, such as actinomycin $\mathrm{D}$, to the culture medium. Actinomycin $\mathrm{D}$ binds to guanine bases in DNA strands to interfere with DNAdependent RNA polymerases and then to inhibit RNA synthesis, causing notable morphological changes in nucleoli. Although this drug inhibits all kinds of RNA synthesis, the most preferential target is rDNA $(32,47,57)$. When 0.05 to $1 \mu \mathrm{g} / \mathrm{ml}$ AMD was added to the culture medium of SL-29 cells for $6 \mathrm{hr}$ and immunofluorescence with anti-36 kDa polyclonal antibody was studied, we observed that the bright nucleolar fluorescence obtained in control cells changed to a labelling restricted to crescent zones and an intense nuclear fluorescence which suggested a translocation of such protein from the nucleolus to the nucleoplasm. Several authors have described this effect induced on protein B23 during treatment with certain anti-tumor drugs such as AMD (6), luzopeptin (59), doxorubicin (8), camptothecin (6) and toyocamycin (58). These studies have indicated that the "B23 translocation assay" is a simple and rapid method of determining the efficacy of these agents on anti-tumor treatments. However, other nucleolar proteins such as nucleolin and fibrillarin have been described as not being so sensitive to translocation under the same conditions as protein B23 (7). Nevertheless, in SL-29 cells, we found a translocation of the $100 \mathrm{kDa}$ Ag-NOR protein induced under the same conditions as these applied to the study of the $36 \mathrm{kDa}$ protein. Scattering of Ag-NOR proteins in Ishikawa cells induced by AMD has also been described, and demonstrated to be dose-dependent (56). These authors suggest that AMD affects intranucleolar DNA, inhibiting rRNA synthesis and provoking nucleolar segregation, from which Ag-NOR proteins leave towards the nucleoplasm, forming fibrillar bodies together with other nucleolar proteins, but without any rDNA. Other studies using different experimental approaches have arrived at the conclusion that both nucleolar proteins shuttle constantly between nucleus and cytoplasm, and suggest a role of these major nucleolar proteins in the nucleocytoplasmic transport of ribosomal components, and that the transient exposure of the shuttling proteins to the cytoplasm may provide a mechanism for cytoplasmic regulation of nuclear activities (5).

We continued with the study at the ultrastructural level of the immunolocalization of major AgNOR proteins on SL-29 cells after treatment with AMD, and observed that the distribution of gold particles was mostly restricted to the granular zone of segregated nucleoli, which morphologically may represent the bright crescent zones observed under immunofluorescence microscopy. However, we were not able to detect a nucleoplasmic labelling that could parallel our observations on immunofluorescence microscopy. In this regard, Biggiogera et al. (4) did not find either a redistribution of $\mathrm{B} 23$ protein to the nucleoplasm in the conditions of a physiological diminished rRNA synthesis existing in Golgi phase spermatids. However, our immunocytochemical results are not in accordance with the observations of other authors who have immunolocated the $100 \mathrm{kDa}$ protein on the fibrillar zone of nucleoli where rDNA 
transcription had been blocked with AMD (19). Likewise, in the case of AMD treatment, our immunolabelling results do not agree with the finding that Ag-NOR proteins have been localized to the fibrillar zone of segregated nucleoli of different types of cells after applying NOR-silver staining (26, 27, 34, 56). Notwithstanding, Biggiogera et al. (4) have found that as nucleolar inactivation progresses through cap phase spermatids, the signal for B23, and later for C23 disappears completely, and affirm that neither the level of B23 nor the level of nucleolin completely parallels the level of nucleolar activity, nor the staining with silver salts.

To further study the functional role of these proteins we assayed the introduction of our polyclonal antibodies against the major $100 \mathrm{kDa}$ and $36 \mathrm{kDa} \mathrm{Ag-}$ NOR proteins into the nucleus of TG cells whose nucleolar structure has already been intensely studied. To better understand the modifications induced with these antibodies on nucleoli, we first analyzed the alterations provoked with the electroporation technique. On TG electroporated control cells we observed voluminous nucleoli which disclosed statistical differences when compared to normal TG nucleoli. This increase in nucleolar area could be due to the nucleolar response against the damage induced by a physical stress, leading to a rRNA synthesis reactivation which is morphologically reflected on a larger number of small fibrillar centres and on the increase in nucleolar size. When our antibody against $36 \mathrm{kDa}$ Ag-NOR protein was added to the electroporation medium, and after a period of $6 \mathrm{hr}$ in culture, we noted that the morphology of nucleoli had changed, disclosing a granular component revealing a structure made of numerous granules perfectly individualized and interstices, and also that nucleolar size was similar to that of TG electroporated control cells. These data, together with the increase in nucleolar size when compared to normal TG cells and to the small size fibrillar centres, allow us to think that reactivation of nucleoli seems to be taking place and, considering the immunolocalization of this protein, to suggest that this antibody is able to induce the blocking of certain proteins involved in the late events of ribonucleoprotein processing. On the other hand, our antibody against $100 \mathrm{kDa} \mathrm{Ag}-\mathrm{NOR}$ protein did not induce any statistical difference on nucleolar size compared to normal TG cells, although nucleoli appeared with a segregation of the fibrillar components, after a period of $6 \mathrm{hr}$ in culture, which indicates an inactivity state in the rRNA biosynthesis events. These results, together with the immunolocalization of the $100 \mathrm{kDa}$ protein mainly over the DFC, allow us to think that the impairment must take place on the early stages of transcription and processing of rRNA occurring on the fibrillar component of nucleoli. Different data were obtained by means of microinjection of anti-C23 antibody into nuclei of Chironomus salivary gland cells, as the authors found a stimulation on the synthesis of pre-rRNA with little effect on processing of the rRNA precursors (16). However, they consider these results as somewhat paradoxical and explain that rDNA transcription, rRNA maturation and ribosome assembly are under common mechanisms and that the rate of transcription may be governed by the rate of the entire assembly process. They suggest a role of protein C23 in regulation of rRNA transcription and that a feedback mechanism may be needed to prevent build-up of excess nascent RNA when other preribosomal components are limited in supply.

In conclusion, after the application of morphological, morphometrical, cytochemical and immunocytochemical techniques, and the study of nucleolar behaviour following the impairment of rDNA transcription by means of an AMD treatment or the blocking of major Ag-NOR proteins by means of electroporation methods, our results suggest that the functional role of the $100 \mathrm{kDa}$ and $36 \mathrm{kDa}$ Ag-NOR proteins, localized to different nucleolar components, is closely related to the nucleolar ribosomal biosynthesis. Likewise, our study corroborates that the $36 \mathrm{kDa}$ Ag-NOR protein would be involved in the late events of processing of ribonucleoproteins while the $100 \mathrm{kDa}$ protein would have a role on the early stages of transcription and processing of rRNA. However, the contradictory results obtained after applying our polyclonal antibodies and NOR-silver staining have opened a new door to study the existence of other possible Ag-NOR proteins that could explain these differences. Finally, we believe that the combination of these techniques could be considered a useful tool to deepen the study of Ag-NOR proteins and, furthermore, we think that the electroporation system could play a key role in elucidating the functional role of the different nucleolar proteins, and to deepen on the knowledge about the mechanisms of regulation of cell activity.

\section{ACKNOWLEDGMENTS}

We are most grateful to Dr. Villalobos (Hospital Vigil de Quiñones) for the maintenance of the animals needed for this study. We also acknowledge $\mathrm{R}$. García Navarro and the Servicio de Microscopía Electrónica (Universidad de Sevilla), in particular J. M. Sanabria and A. Estefane, for their technical 
assistance. This work was partially supported by the DGICYT (Projects no. PB90-0904 and PB92-0680).

\section{REFERENCES}

1. Bendayan, M., Roth, J., Perrelet, A. and Orci, L.: Quantitative immunocytochemical localization of pancreatic secretory proteins in subcellular compartments of the rat acinar cell. J. Histochem. Cytochem. 28; 149-160, 1980.

2. Biggiogera, M., Bürki, K., Kaufmann, S. H., Sharper, J. H., Gas, N., Amalric, F. and Fakan, S.: Nucleolar distribution of proteins B23 and nucleolin in mouse preimplantation embryos as visualized by immunoelectron microscopy. Development 110; 1263-1270, 1990.

3. Biggiogera, M., Fakan, S., Kaufmann, S. H., Black, A., Shaper, J. H. and Busch, H.: Simultaneous immunoelectron microscopic visualization of protein B23 and C23 distribution in the HeLa cell necleolus. J. Histochem. Cytochem. 37; 1371-1374, 1989.

4. Biggiogera, M., Kaufmann, S. H., Shaper, J. H., Gas, N., Amalric, F. and Fakan, S.: Distribution of nucleolar proteins B23 and nucleolin during mouse spermatogenesis. Chromosoma 100; 162-172, 1991.

5. Borer, R. A., Lehner, C. F., Eppenberger, H. M. and Nigg, E. A.: Major nucleolar proteins shuttle between nucleus and cytoplasm. Cell 56; 379-390, 1989.

6. Chan, P. K.: Characterization and cellular localization of nucleophosmin/B23 in HeLa cells treated with selected cytotoxic agents (studies of B23-translocation mechanism). Exp. Cell. Res. 203; 174-181, 1992.

7. Chan, P. K., Aldrich, M. and Busch, H.: Alterations in immunolocalization of the phosphoprotein B23 in HeLa cells during serum starvation. Exp. Cell. Res. 161; 101110, 1985.

8. Chan, P. K., Aldrich, M. B. and Yung, B. Y. M.: Nucleolar protein B23 translocation after doxorubicin treatment in murine tumor cells. Cancer Res. 47; 37983801, 1987.

9. Chang, D. C., Hunt, J. R., Zheng, Q. and Gao, P. Q.: Electroporation and electrofusion using a pulsed radio-frequency electric field. In "Guide to Electroporation and Electrofusion”, ed. by D. C. Chang, B. M. Chassy, J. A. Saunders and A. E. Sowers, Academic Press, San Diego, 1992, pp. 303-326.

10. Charpin, C., Bonnier, P., Piana, L., Kouzhami, H., Devictor, B., Lavaut, M. N., Andrac, L. and Allasia, C.: Correlation of nucleolar organizer regions and nuclear morphometry assessed by automatic image analysis in breast cancer with aneuploidy, K167 immunostaining, histopathological grade and lymph node involvement. Path. Res. Pract. 188; 1009-1017, 1992.

11. De Capoa, A., Ferraro, M., Lavia, P., Pelliccia, F. and Finazzi-Agrò, F.: Silver staining of the nucleolus organizer regions (NOR) requires clusters of sulfhydryl groups. J. Histochem. Cytochem. 30; 908-911, 1982.

12. Derenzini, M., Farabegoli, F. and Trerè, D.: Relation- ship between interphase AgNOR distribution and nucleolar size in cancer cells. Histochem. J. 24; 951-956, 1992.

13. Derenzini, M. and Ploton, D.: Interphase nucleolar organizer regions in cancer cells. Int. Rev. Exp. Pathol. 32; 150-192, 1991.

14. Derenzini, M., Thiry, M. and Goessens, G.: Ultrastructural cytochemistry of the mammalian cell nucleolus. $J$. HIstochem. Cytochem. 38; 1237-1256, 1990.

15. Edwards, S., Afford, S. and Crocker, J.: The effect of inducing agents on the numbers of interphase fibrillar centers in the U937 promonocytic cell line. Exp. Cell Res. 194; 118-121, 1991.

16. Egyhazi, E., Pigon, A., Chang, J. H., Ghaffari, S. H., Dreesen, T. D., Wellman, S. E., Case, S. T. and Olson, M. O. J.: Effects of anti-C23 (nucleolin) antibody on transcription of ribosomal DNA in Chironomus salivary gland cells. Exp. Cell Res. 178; 264-272, 1988.

17. Einck, L. and Bustin, M.: Functional histone antibody fragments traverse the nuclear envelope. J. Cell Biol. 98; 205-213, 1984.

18. Escande, M. L., Gas, G. and Stevens, B. J.: Immunolocalization of the $100 \mathrm{~K}$ nucleolar protein in $\mathrm{CHO}$ cells. Biol. Cell 53; 99-110, 1986.

19. Escande-Géraud, M. L., Azum, M. C., Tichadou, J. L. and Gas, N.: Correlation between rDNA transcription and distribution of a $100 \mathrm{KD}$ nucleolar protein in $\mathrm{CHO}$ cells. Exp. Cell Res. 161; 353-363, 1985.

20. Feuerstein, N., Chan, P. K. and Mondi, J. J.: Identification of numatrin, the nuclear matrix protein associated with induction of mitogenesis, as the nucleolar protein B23. J. Biol. Chem. 263; 10608-10612, 1988.

21. Fischer, D., Weisenberger, D. and Scheer, U.: Assigning functions to nucleolar structures. Chromosoma 101; 133-140, 1991.

22. Goodpasture, C. and Bloom, S. E.: Visualization of nucleolar organizer regions in mammalian chromosomes using silver staining. Chromosoma 53; 37-50, 1975.

23. Haaf, T., Reimer, G. and Schmid, M.: Immunocytogenetics: localization of transcriptionally active rRNA genes in nucleoli and nucleolus organizer regions by use of human autoantibodies to RNA polymerase I. Cytogenet. Cell Genet. 48; 35-42, 1988.

24. Harlow, E. D. and Lane, D.: Immunizations. In "Antibodies, a Laboratory Manual”, Cold Spring Harbor Laboratory: New York, 1988, pp. 53-137.

25. Hernandez-Verdun, D.: The nucleolus today. J. Cell Sci. 99; 465-471, 1991.

26. Hernandez-Verdun, D., Derenzini, M. and Bouteille, M.: Relationship between the Ag-NOR proteins and ribosomal chromatin in situ during drug-induced RNA synthesis inhibition. J. Ultrastruct. Res. 88; 55-65, 1984.

27. Hernandez-Verdun, D., Hubert, J., Bourgeois, C. A. and Bouteille, M.: Ultrastructural localization of AgNOR stained proteins in the nucleolus during the cell cycle and in other nucleolar structures. Chromosoma 79; 349-362, 1980.

28. Howell, W. M. and Black, D. A.: Controlled silver-staining of nucleolus organizer regions with a protective-col- 
loidal developer: a 1-step method. Experientia 36; 10141015, 1980.

29. Laemmli, U. K.: Cleavage of structural proteins during the assembly of the head of bacteriophage T4. Nature 227; 680-685, 1970.

30. Lesty, C., Chleq, C., Contesso, G. and Jacquillat, C.: Nucleoli and AgNOR proteins in 32 cases of primary breast carcinoma. Analyt. Quant. Cytol. Histol. 14; 175186, 1992.

31. Lischwe, M. A., Richards, R. L., Busch, R. K. and Busch, H.: Localization of phosphoprotein C23 to nucleolar structures and to the nucleolus organizer regions. Exp. Cell Res. 136; 101-109, 1981.

32. Miller, M.J.: Sensitivity of RNA synthesis to actinomycin $\mathrm{D}$ inhibition is dependent on the frequency of transcription: a mathematical model. J. Theor. Biol. 129; 289-299, 1987.

33. Moreno, F. J., Hernandez-Verdun, D., Masson, C. and Bouteille, M.: Silver staining of the nucleolar organizer regions (NORs) on Lowicryl and cryo-ultrathin sections. J. Histochem. Cytochem. 33; 389-399, 1985.

34. Moreno, F. J., Rodrigo, R. M. and Garcia-Herdugo, G.: An experimental approach to nucleolar organization in plant cells: a morphological, cytochemical and quantitative study. J. Cell Sci. 94; 51-59, 1989.

35. Moreno, F.J., Rodrigo, R. M., Garcia-Herdugo, G.: Ag-NOR proteins and rDNA transcriptional activity in plant cells. J. Histochem. Cytochem. 38; 1879-1887, 1990.

36. Olmsted, J. B.: Affinity purification of antibodies from diazotized paper blots of heterogeneous protein samples. J. Biol. Chem. 256; 11955-11957, 1991.

37. Pession, A., Farabegoli, F., Trerè, D, Novello, F., Montanaro, L., Sperti, S., Rambelli, F. and Derenzini, M.: The Ag-NOR proteins and transcription and duplication of ribosomal genes in mammalian cell nucleoli. Chromosoma 100; 242-250, 1991.

38. Pich, A., Chiusa, L., Marmont, F., Cappello, N. and Navone, R.: Argyrophilic nucleolar organizer region counts in multiple myeloma: a histopathological study on bone marrow trephine biopsies. Virchows Archiv A Pathol. Anat. 421; 143-147, 1992.

39. Ploton, D., Bobichon, H. and Adnet, J. J.: Ultrastructural localization of NOR in nucleoli of human breast cancer tissues using a one-step AG-NOR staining method. Biol. Cell 43; 229-232, 1982.

40. Ploton, D., Visseaux-Colletto, B., Canellas, J. C., Bourzat, C., Adnet, J.J., Lechki, C. and Bonnet, N.: Semiautomatic quantification of silver-stained nucleolar organizer regions in tissue sections and cellular smears. Analyt. Quant. Cytol. Histol. 14; 14-23, 1992.

41. Rendon, M. C., Rodrigo, R. M., Goenechea, L. G., Garcia-Herdugo, G., Valdivia, M. M. and Moreno, F. J.: Characterization and immunolocalization of a nucleolar antigen with anti-NOR serum in HeLa cells. Exp. Cell Res. 200; 393-403, 1992.

42. Roth, J.: Application of lectin-gold complexes for electron microscopic localization of glycoconjugates of thin sections. J. Histochem. Cytochem. 31; 897-999, 1983.

43. Roth, J., Taatjes, D. J. and Warhol, M. J.: Prevention of nonspecific interactions of gold-labeled reagents on tissue sections. Histochemistry 92; 47-56, 1989.

44. Roussel, P., Belenguer, P., Amalric, F. and HernandezVerdun, D.: Nucleolin is an Ag-NOR protein: this property is determined by its amino-terminal domain independently of its phosphorylation state. Exp. Cell Res. 203; 259-269, 1992.

45. Scheer, U., Thiry, M. and Goessens, G.: Structure, function and assembly of the nucleolus. Trends Cell Biol. 3; 236-241, 1993.

46. Schmidt-Zachmann, M. and Franke, W. W.: DNA cloning and amino acid sequence determination of a major constituent protein of mammalian nucleoli. Correspondence of the nucleoplasmin-related protein NO38 to mammalian protein B23. Chromosoma 96; 417-426, 1988.

47. Snyder, J. G., Hartman, N. G., Langlois, B., Kennard, O., Remeta, D. P. and Breslauer, K. J.: Binding of actinomycin D to DNA: evidence for a nonclassical highaffinity binding mode that does not require $\mathrm{GpC}$ sites. Proc. Natl. Acad. Sci. 86; 3968-3972, 1989.

48. Spector, D. L., Ochs, R. L. and Busch, H.: Silver staining, immunofluorescence, and immunoelectron microscopic localization of nucleolar phosphoproteins B23 and C23. Chromosoma 90; 139-148, 1984.

49. Spurr, A. R.: A low viscosity epoxy resin embedding medium for electron microscopy. J. Ultrastruct. Res. 26; 31-33, 1969.

50. Stacey, D. W. and Allfrey, V. G.: Microinjection studies of protein transit across the nuclear envelope of human cells. Exp. Cell Res. 154; 283-292, 1984.

51. Stochaj, U. and Silver, P.: Nucleocytoplasmic traffic of proteins. Eur. J. Cell Biol. 59; 1-11, 1992.

52. Towbin, H., Staehelim, T. and Gordon, J.: Electrophoretic transfer of proteins from polyacrylamide gels to nitrocellulose sheets: procedure and some applications. Proc. Natl. Acad. Sci. USA 76; 4350-4354, 1979.

53. Tsong, T.Y.: Electroporation of cell membranes. Biophys. J. 60; 297-306, 1991.

54. Wang, D., Umekawa, H. and Olson, M. O. J.: Expression and subcellular locations of two forms of nucleolar protein B23 in rat tissues and cells. Cell. Molec. Biol. Res. 39; 33-42, 1993.

55. Weaver, J. C.: Electroporation: a general phenomenon for manipulating cells and tissues. J. Cell Biochem. 51; 426-435, 1993.

56. Yokoyama, Y., Niwa, K. and Tamaya, T.: Scattering of the silver-stained proteins of nucleolar organizer regions in Ishikawa cells by actinomycin D. Exp. Cell Res. 202; 77-86, 1992.

57. Yu, F. L. and Bender, W.: Actinomycin D binding in vitro: active chromatin preferred. Biochem. Int. 20; 807815, 1990.

58. Yung, B. Y. M., Busch, H. and Chan, P. K.: Translocation of nucleolar phosphoprotein $\mathrm{B} 23(37 \mathrm{KDa} / \mathrm{pI} 5.1)$ induced by selective inhibitors of ribosome synthesis. Biochim. Biophys. Acta 826; 167-173, 1985.

59. Yung, B. Y. M., Busch, H. and Chan, P. K.: Effects of luzopeptins on protein B23 translocation and ribosomal RNA synthesis in HeLa cells. Cancer Res. 46; 922-925, 1986. 